\title{
Glucose transporters in obesity
}

\author{
BY MICHÈLE GUERRE-MILLO \\ U 177 INSERM, Institut Biomédical des Cordeliers, 15 rue de l'Ecole de Médecine, \\ 75006 Paris, France
}

\section{Les transporteurs de glucose dans l'obésité}

\begin{abstract}
RÉSUMÉ
L'obésité, pathologie fréquente dans les sociétés industrialisées, est caractérisée par un sur-développement du tissu adipeux. Nous avons étudié un modèle animal d'obésité, le rat Zucker génétiquement obèse. Dès l'âge de 30 jours, les cellules adipeuses des rats mutants transportent beaucoup plus de glucose que celles des témoins normaux des mêmes portées. Cette anomalie repose sur une augmentation du nombre des transporteurs de glucose et plus particulièrement sur une surexpression de l'isoforme GLUT4. La régulation de l'expression de GLUT4 par le génotype $(f a)$ est spécifique du tissu adipeux. De plus, nous avons montré récemment qu'elle passe par une suractivation du promoteur. La surexpression de GLUT4 permet une entrée massive de glucose dans les cellules adipeuses, favorisant une lipogénèse excessive. Ultérieurement, les niveaux adipocytaires de GLUT4 diminuent, en conjonction avec l'apparition d'une insulinorésistance. Chez l'homme obèse, la diminution de l'expression de GLUT4 dans le tissu adipeux est aggravée par le diabète non-insulino dépendant (DNID), un défaut qui concerne également une autre isoforme GLUT5, transporteur de fructose. L'implication de GLUT5 dans l'utilisation des hexoses par la cellule adipeuse et son rôle dans le DNID restent à déterminer.
\end{abstract}

Obesity is a common human health problem in industrialized societies and is characterized by increased adipose tissue mass. Obesity is highly correlated with insulin resistance and non-insulin-dependent diabetes mellitus (NIDDM). However, the molecular mechanisms involved in these syndromes are still poorly understood. In addition to defects in systems which regulate food intake and energy expenditure, one cellular site at which potential abnormalities might reside is the adipose cell.

The adipose cell is devoted to storing energy in the form of triacylglycerols, which are synthesized through two major pathways: lipogenesis from glucose and esterification of free fatty acids. The latter pathway also utilizes glucose for the production of the $\mathrm{C}_{3}$ skeleton of glycerol. The relative contributions of these pathways to lipid formation varies with pathophysiological conditions, including ageing. A major control point for both is the transport of glucose into the adipose cell. Glucose uptake is mediated by specialized integral membrane proteins, the facilitative glucose transporters (GLUT). Until now, six isoforms have been discovered, each having specific tissue distribution and kinetic properties. At least three GLUT isoforms are expressed in adipose cells: GLUT1, which is also present in many other tissues; GLUT4, which is expressed almost 
exclusively in tissues where glucose transport activity is acutely regulated by insulin (i.e. adipose tissues and muscle); GLUT5, which has been detected in human adipose cells and is thought to transport fructose preferentially.

The present review focuses on the alterations in glucose transport and glucose transporter expression in adipose cells in an animal model of obesity, the Zucker fatty rat. Recent data obtained from obese human subjects with or without NIDDM will also be presented.

\section{AN ANIMAL MODEL OF OBESITY: THE ZUCKER FATTY RAT}

The genetically-obese falfa rat, first described by Zucker \& Zucker (1961), expresses an autosomal recessive mutation, the $f a$ gene. The mutation has been mapped recently to chromosome 5 (Truett et al. 1991), but the protein remains totally obscure. The rats develop a syndrome with multiple metabolic and hormonal disorders which closely resembles human obesity. Hyperphagia, hyperinsulinaemia and hypertriacylglycerolaemia are features common to both species. Therefore, the unravelling of biochemical defects in these rats might lead to a better understanding of human obesity.

The obesity of the Zucker rat is of early onset. In suckling obese pups ( $16 \mathrm{~d}$ of age), adipose tissue mass and fat cell size are already twice those observed in lean littermates; however, insulinaemia is similar in both genotypes (Table 1). At weaning (about $25 \mathrm{~d}$ of age), the rate of adipose tissue growth accelerates dramatically, along with the emergence of hyperphagia and hyperinsulinaemia. By $30 \mathrm{~d}$ of age, the obese rats display 4-5-fold higher adipose tissue mass and fat cell size than lean littermates and are markedly hyperinsulinaemic (Table 1).

\section{GLUCOSE TRANSPORT ACTIVITY IN ADIPOSE CELLS}

Cushman et al. (1978) and Czech et al. (1978) have previously shown an increase in insulin's stimulatory effect on glucose transport in isolated epididymal adipose cells from

Table 1. General characteristics of young Zucker rats

(Mean values with their standard errors for eighteen determinations)

\begin{tabular}{|c|c|c|c|c|c|c|c|c|}
\hline \multirow[t]{3}{*}{ Age (d) } & \multicolumn{4}{|c|}{16} & \multicolumn{4}{|c|}{30} \\
\hline & \multicolumn{2}{|c|}{ Lean $(F a / f a)$} & \multicolumn{2}{|c|}{ Obese $(f a / f a)$} & \multicolumn{2}{|c|}{ Lean ( $F a / f a)$} & \multicolumn{2}{|c|}{ Obese $(f a / f a)$} \\
\hline & Mean & SE & Mean & $\mathrm{SE}$ & Mean & SE & Mean & $\mathrm{SE}$ \\
\hline Body wt (g) & $24 \cdot 5$ & $0 \cdot 30$ & $26 \cdot 2^{*}$ & $0 \cdot 27$ & $58 \cdot 2$ & $1 \cdot 3$ & $63 \cdot 7^{*}$ & $1 \cdot 3$ \\
\hline $\begin{array}{l}\text { Inguinal adipose pads } \\
\text { weight (g) }\end{array}$ & $0 \cdot 13$ & 0.01 & $0 \cdot 33^{*}$ & $0 \cdot 01$ & $0 \cdot 52$ & $0 \cdot 02$ & $1 \cdot 81^{*}$ & $0 \cdot 12$ \\
\hline $\begin{array}{l}\text { Adipose cell size } \\
(\mu \mathrm{g} \text { lipid/cell })\end{array}$ & $0 \cdot 016$ & $0 \cdot 002$ & $0 \cdot 045^{*}$ & $0 \cdot 004$ & $0 \cdot 040$ & 0.003 & $0 \cdot 18^{*}$ & $0 \cdot 01$ \\
\hline $\begin{array}{l}\text { Adipose cell surface } \\
\text { area }\left(\mu \mathrm{m}^{2} \times 10^{-3}\right)\end{array}$ & $3 \cdot 0$ & $0 \cdot 26$ & $6 \cdot 1^{*}$ & $0 \cdot 39$ & $4-7$ & $0 \cdot 31$ & $14 \cdot 5^{*}$ & $0 \cdot 30$ \\
\hline Plasma glucose (mM) & $7 \cdot 94$ & $0 \cdot 12$ & $8 \cdot 44^{*}$ & $0 \cdot 23$ & $9 \cdot 16$ & 0.38 & $8 \cdot 65$ & $0 \cdot 15$ \\
\hline Plasma insulin (nM) & $0 \cdot 15$ & $0 \cdot 02$ & $0.17^{*}$ & $0 \cdot 01$ & 0.28 & 0.03 & $0 \cdot 74 *$ & $0 \cdot 13$ \\
\hline
\end{tabular}

Mean values for obese rats were significantly different from those of lean rats: ${ }^{*} P<0 \cdot 01$. 

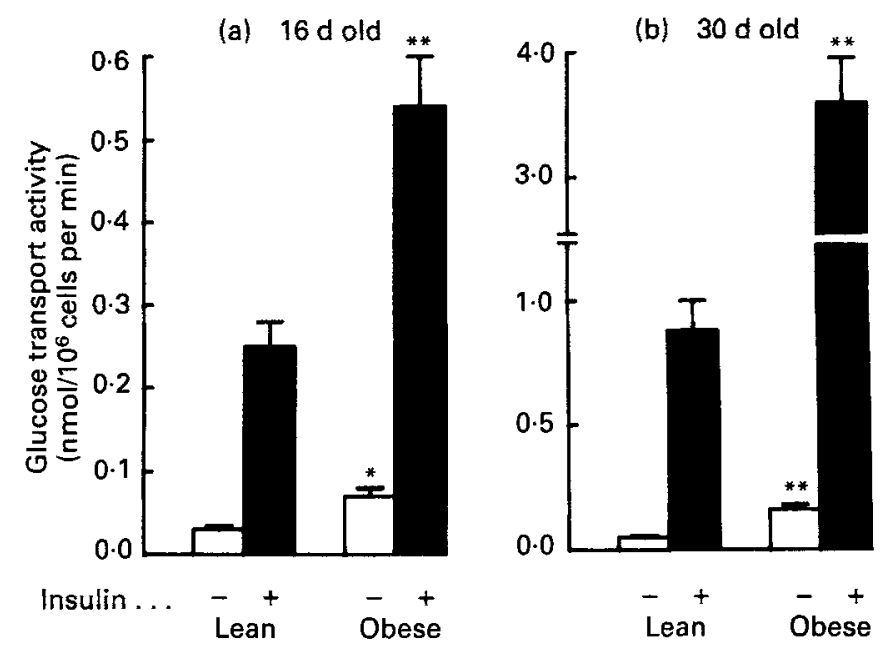

Fig. 1. Glucose transport activity in isolated adipose cells from young lean and obese Zucker rats at 16 and $30 \mathrm{~d}$ of age. ( $\square$ ), Basal (without insulin); ( $\mathbf{\square}),+$ insulin $(0.72 \mathrm{nM})$. Values are means with their standard errors represented by vertical bars.
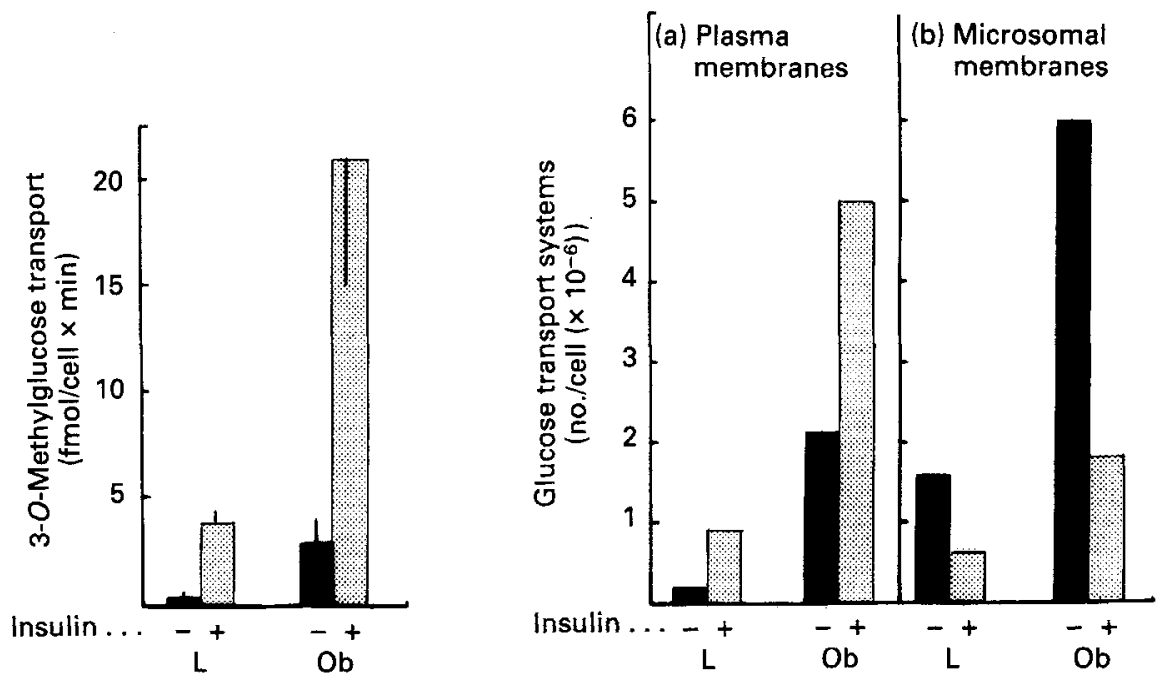

Fig. 2. Glucose transport activity and the number of glucose transporters measured by cytochalasin-B binding in adipose cells from lean (L) and obese $(\mathrm{Ob}) 30$-d-old Zucker rats. ( $\square$ ), Basal (without insulin); (需), + insulin $(0.72 \mathrm{~nm})$. Values are means with their standard errors represented by vertical bars.

6- and 10-week-old obese Zucker rats. In good agreement, we have observed that inguinal adipose cells from 30 -d-old obese Zucker rats exhibit a several-fold increase in glucose transport activity as compared with lean littermates (Fig. 1). These observations are consistent with our in vivo studies demonstrating that the hypertrophied inguinal adipose tissue from obese rats utilizes 10 -fold more glucose than the adipose tissue from lean littermates (Krief et al. 1988). In addition, enhanced glucose transport activity of 
adipose cells, although less marked, is already apparent in suckling obese pups at $16 \mathrm{~d}$ of age (Fig. 1).

In a first attempt to delineate the molecular mechanisms underlying the enhanced glucose transport in the obese rat fat cells, we measured the number of glucose transporters (Guerre-Millo et al. 1985). Using the cytochalasin-B binding method, we were able to determine that the number of glucose transporters in the low-density microsomes is dramatically increased in the obese rats (Fig. 2). In adipose cells, this intracellular membrane fraction represents a storage compartment from which glucose transporters are translocated to the plasma membrane in response to insulin binding to its membrane receptor. The increased size of the intracellular reserve results in more glucose transporters reaching the plasma membrane following insulin stimulation. It is apparent from Fig. 2 that a good correlation is observed between glucose transport activity in lean and obese rat fat cells and the number of glucose transporters at the cell surface. This was the first demonstration of an increased intracellular pool of glucose transporter in an insulin-hyper-responsive cell. Interestingly, this situation is the opposite of that occurring in insulin-resistant adipose cells from diabetic or fasted rats (for review, see Kahn, 1992).

\section{OVEREXPRESSION OF GLUT4 IN ADIPOSE CELLS}

The cytochalasin-B binding method does not discriminate between glucose transporter isoforms. When it was discovered that two transporters, GLUT1 and GLUT4, were expressed in rat adipose cells, the question arose as to which isoform is overexpressed in the young obese Zucker rat. Using isoform-specific antibodies, we determined (Hainault et al. 1991) that the concentration of GLUT4 was significantly higher in membranes prepared from obese-rat adipose cells than in those from lean rats, whereas the concentration of GLUT1 was similar at $16 \mathrm{~d}$ of age or lower at $30 \mathrm{~d}$ of age. With larger cells in the obese rat, total cellular content of GLUT4 was $2 \cdot 4$ - and $4 \cdot 5$-fold higher at 16 and $30 \mathrm{~d}$ of age respectively. In contrast, the amounts of GLUT1 per cell were similar in the two genotypes. As shown in Fig. 3, the increase in insulin-stimulated glucose transport activity in obese, relative to lean, rat fat cells is fully accounted for by the increase in the cellular content of GLUT4. In addition, the overexpression of GLUT4 is specific to white adipose tissue, as GLUT4 levels are unchanged in skeletal muscle (Hainault et al. 1991) and tend to be decreased in brown adipose tissue in obese $v$. lean pups (Charron et al. 1995).

Hyperinsulinaemia is already apparent in 30-d-old obese Zucker rats (Table 1), suggesting that this might be the underlying cause of the differential expression of GLUT isoforms in adipose cells as compared with normo-insulinaemic lean controls. Indeed, a similar pattern of regulation, in which an increase in GLUT4 expression is associated with unchanged GLUT1 is also observed in adipose cells from rats whose insulinaemia was increased by refeeding after a fast or insulin treatment of streptozotocin diabetes (Kahn, 1992). However, we observed that the overexpression of GLUT4 is already present at $16 \mathrm{~d}$ of age in normo-insulinaemic obese pups (Fig. 3). This suggests that the $f a$-dependent up-regulation of GLUT4 expression is independent of hyperinsulinaemia.

These observations strongly suggest that early overexpression of GLUT4 in adipose tissue resulting in increased glucose uptake is involved in the development of obesity. This alteration could be responsible for the preferential shunting of glucose into adipose 

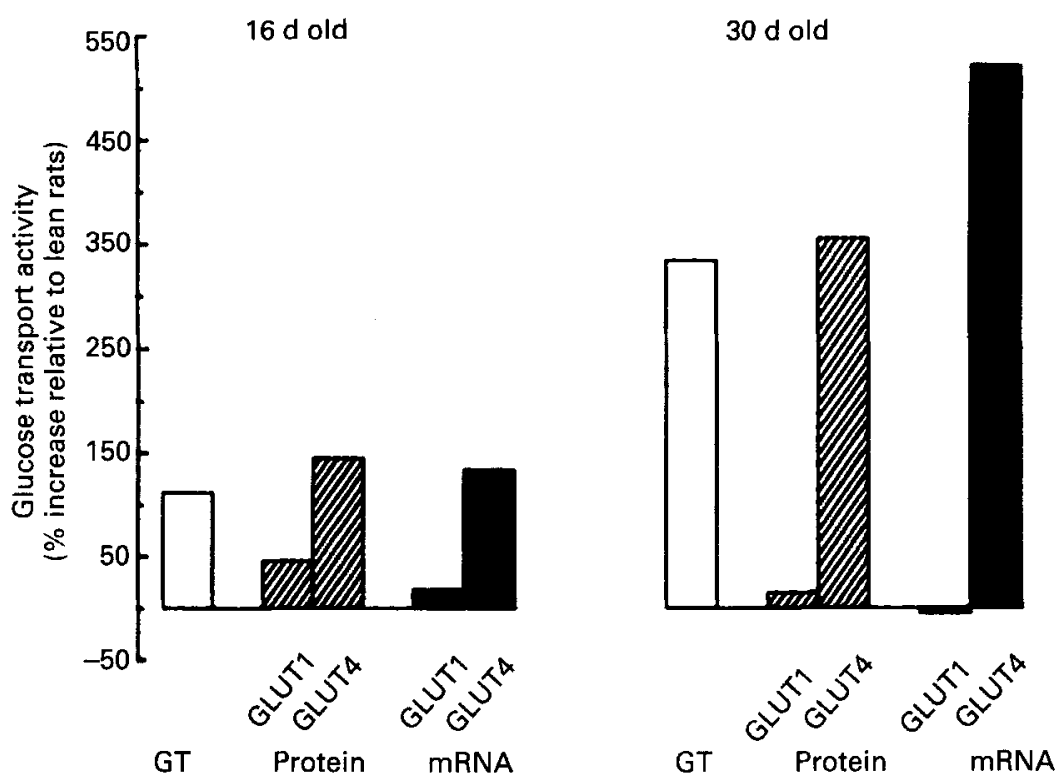

Fig. 3. Genotype effect on insulin-stimulated glucose transport (GT, $\square$ ), GLUT1 and GLUT4 protein per adipose cell (ש) and GLUT1 and GLUT4 mRNA per fat pad (E). Results in obese rats at 16 and $30 \mathrm{~d}$ old are expressed as the percentage increase relative to corresponding values for lean rats.

tissue triacylglycerols which characterizes the obese phenotype in the Zucker rat. Interestingly, increased GLUT4 expression in adipose cells has been reported in other rodent models of obesity such as ventromedial hypothalamus-lesioned rats (Cousin et al. 1992) and mice made obese by gold thioglucose injection (Le Marchand-Brustel et al. 1990). More recently, the availability of several lines of transgenic mice overexpressing GLUT4 in adipose tissue, which develop obesity, has reinforced the potential role of GLUT4 overexpression in fat (Liu et al. 1993; Shepherd et al. 1993).

\section{DECREASED EXPRESSION OF GLUT4 IN AGED OBESE RATS}

Although a marked overexpression of GLUT4 in adipose cells is observed early in life, i.e. in the dynamic phase of the development of obesity, it has been shown that 20-week-old obese Zucker rats have less GLUT4 per cell than lean controls (Pedersen et al. 1992). This suggests that eventually factors which down-regulate GLUT4 overcome the genotype effect. Relevant to these observations, the adipose cell GLUT4 is decreased in the aged (12-month-old) obese Sprague-Dawley rat, along with a decreased intracellular pool of transporters and a decreased insulin effect on glucose transport, as compared with young lean controls (Hissin et al. 1982; Ezaki et al. 1990). The factors responsible for the down-regulation of GLUT4 in adult or aged obese rats, which could be related to long-term hyperinsulinaemia or hyperlipaemia, remain unknown.

\section{MOLECULAR MECHANISMS OF ENHANCED GLUT4 EXPRESSION}

As shown in Fig. 3, the levels of GLUT1 and GLUT4 mRNA closely parallel the levels of the proteins, at both ages and in both genotypes. Similarly, Pénicaud et al. (1991) 

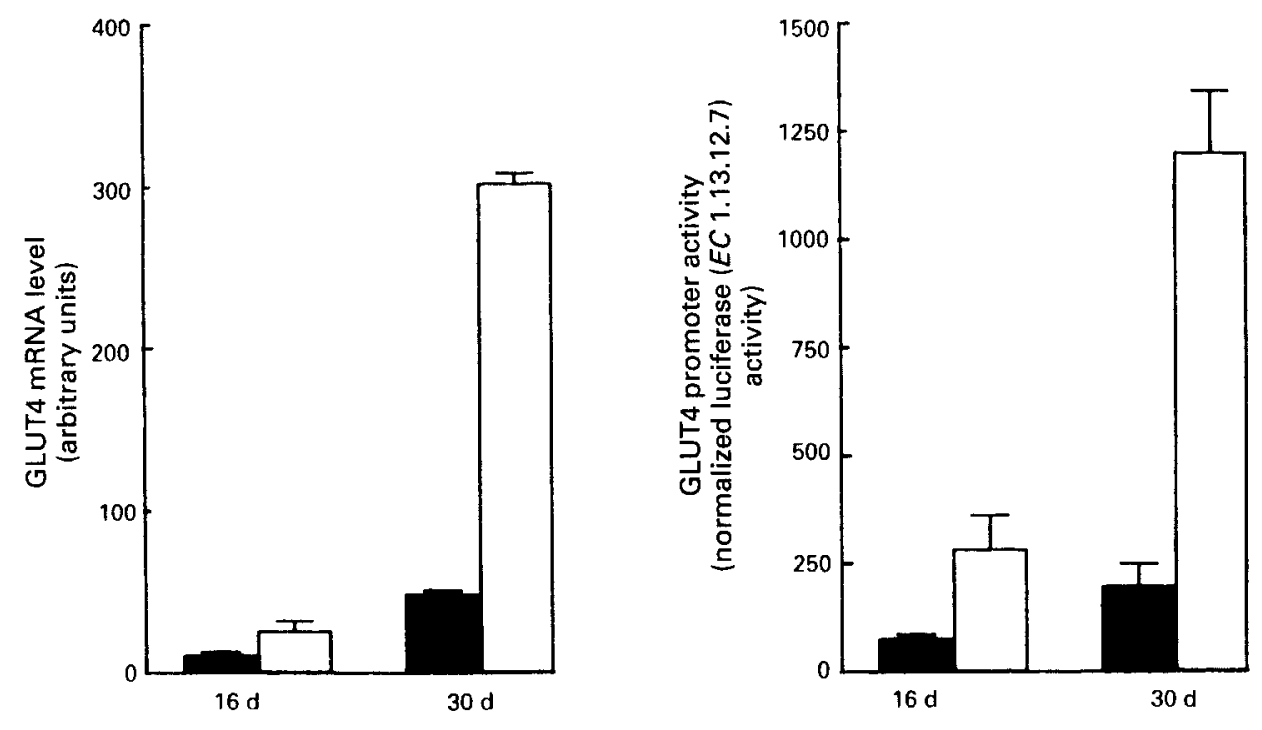

Fig. 4. GLUT4 mRNA and GLUT4 promoter activity in adipose cells from lean ( $\square$ ) and obese ( $\square$ ) Zucker rats. Values are means with their standard errors represented by vertical bars.

reported increased GLUT4 mRNA levels in white adipose tissue from young suckling and weaned obese Zucker rats. This suggests that the transcriptional step could be involved in the $f a$-dependent increase in GLUT4 gene expression. To address this question, we have examined the activity of the rat GLUT4 promoter fused to luciferase (EC 1.13.12.7) in transiently-transfected rat adipose cells (Hainault et al. 1995). As shown in Fig. 4, the transcriptional activity of the GLUT4 promoter is several-fold higher in fat cells from obese rats relative to lean rats, both at 16 and $30 \mathrm{~d}$ of age. Furthermore, the increase in GLUT4 promoter activity in obese $v$. lean parallels the increase in GLUT4 mRNA, strongly suggesting that the fatty genotype regulates GLUT4 gene expression at the transcriptional level. Interestingly, it has been recently shown in our laboratory that fatty acid synthase ( $E C 2.3 .1 .85$; FAS), a key enzyme in lipogenesis from glucose, is also overexpressed in adipose cells from young obese rats, due to an increase in transcription rate and promoter activity (Guichard et al. 1992; Rolland et al. 1995). These findings suggest that the fa gene affects the activity of transcription factors in adipose cells, the nature of which remains to be determined. By activating genes crucial for triacylglycerol synthesis such as GLUT4 and FAS, these fa-dependent transacting factors have the potential to account for the development of obesity.

\section{DYSREGULATION OF GLUT4 AND GLUT5 IN ADIPOSE TISSUE OF OBESE PATIENTS WITH NON-INSULIN-DEPENDENT DIABETES MELLITUS}

A common pathology associated with obesity is insulin resistance and NIDDM. Recent studies have shown that GLUT4 expression is decreased in adipose cells from obese human subjects, a defect which is more profound in obese NIDDM patients (for references, see Bastar et al. 1995). However, although skeletal muscle is thought to be a 
(a) Adipose tissue

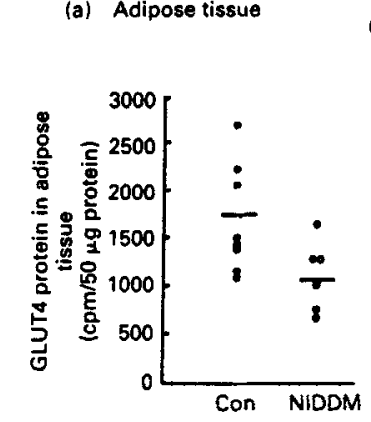

GLUT4

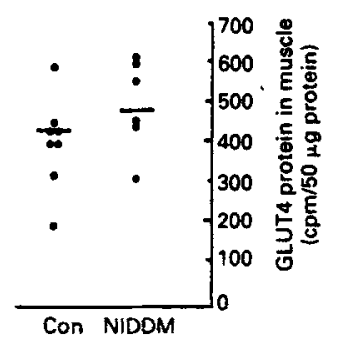

GLUT5

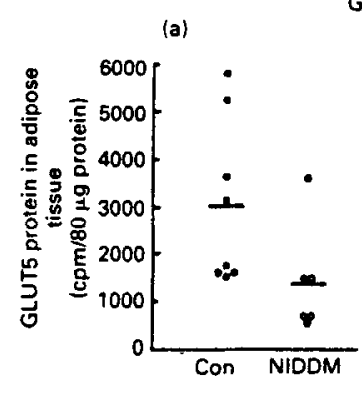

(b) Skeletal muscle

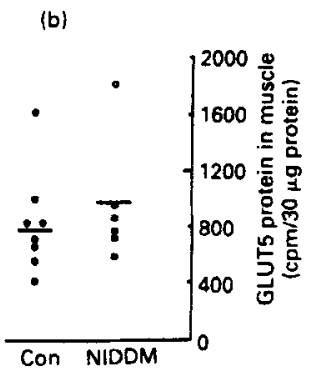

Fig. 5. GLUT4 and GLUT5 concentrations in (a) adipose cells and (b) muscle biopsies obtained from obese patients without (Con) or with non-insulin-dependent diabetes mellitus (NIDDM). cpm, Counts per min.

major site of insulin resistance in NIDDM, normal GLUT4 levels in muscle have been consistently observed (for references, see Bastar et al. 1995), suggesting that other factors, such as decreased GLUT4 activity, might be involved. As shown in Fig. 5, we have recently confirmed these observations using a protocol where GLUT4 concentrations were assessed in skeletal muscle and subcutaneous adipose tissue biopsies obtained from the same patient (Bastar et al. 1995). Furthermore, we observed a similar pattern of alteration for GLUT5, another isoform of transporter expressed in human adipose cells. These observations suggest that the expression of the two isoforms is regulated by common mechanisms. However, the specific role of GLUT5, a putative fructose transporter, in insulin-responsive tissues and its implication in NIDDM requires clarification.

\section{CONCLUSION}

These studies indicate that the expression of glucose transporter proteins in adipose cells is profoundly altered in obesity. Among the isoforms, GLUT4 is the most affected. In the early phase of the syndrome, GLUT4 is markedly overexpressed, a defect which would act as a 'metabolic pull' channelling glucose into triacylglycerols leading to increased fat cell size. Later on, GLUT4 levels decrease in conjunction with insulin resistance and eventually a NIDDM-like state. The molecular mechanisms involved in these dysregulations are yet to be determined. However, these studies emphasize that GLUT4 gene expression in adipose cells is a potential target for therapeutic agents in the treatment or prevention of obesity. 


\section{REFERENCES}

Bastar, J.-P., Hainque, B., Jardel, C., Cohen, S., Bruckert, E., Grimaldi, A., Robert, J. J. \& Guerre-Millo, M. (1995). Tissue specific regulation of GLUT4 and GLUT5 expression in non insulin-dependent diabetes mellitus. Endocrinology and Metabolism 2, 259-268.

Charron, C., Dupuy, F., Marie, V. \& Bazin, R. (1995). Effect of the $\beta$-adrenoceptor agonist BRL-35135 on development of obesity in suckling Zucker ( $f a / f a)$ rats. American Journal of Physiology 268, E1039-E1045.

Cousin, B., Agou, K., Leturque, A., Ferré, P., Girard, J. \& Pénicaud, L. (1992). Molecular and metabolic changes in white adipose tissue of the rat during development of ventromedial hypothalamic obesity. European Journal of Biochemistry 207, 377-382.

Cushman, S. W., Zarnowski, M.-J., Franzusoff, A. J. \& Salans, L. B. (1978). Alteration in glucose metabolism and its stimulation by insulin in isolated adipose cells during the development of genetic obesity in the Zucker fatty rat. Metabolism 27, 1930-1940.

Czech, M. P., Richardson, D. K., Becker, S. G., Walters, C. G., Gitomer, W. \& Heinrich, J. (1978). Insulin response in skeletal muscle and fat cells of the genetically obese Zucker rat. Metabolism 27, 1964-1981.

Ezaki, O., Fukuda, N. \& Itakura, H. (1990). Role of two types of glucose transporters in enlarged adipocytes from aged obese rats. Diabetes 39, 1543-1549.

Guerre-Millo, M., Lavau, M., Horne, J. S. \& Wardzala, L. J. (1985). Proposed mechanism for increased insulin mediated glucose transport in adipose cells from young, obese Zucker rats. Large intracellular pool of glucose transporters. Joumal of Biological Chemistry 260, 2197-2201.

Guichard, C., Dugail, I., Le Liepvre, X. \& Lavau, M. (1992). Genetic regulation of fatty acid synthetase expression in adipose tissue: overtranscription of the gene in genetically obese rats. Journal of Lipid Research $33,679-687$.

Hainault, I., Guerre-Millo, M., Guichard, C. \& Lavau, M. (1991). Differential regulation of adipose tissue glucose transporters in genetic obesity (Fatty rat). Selective increase in adipose cell/muscle glucose transporter (GLUT4) expression. Journal of Clinical Investigation 87, 1127-1131.

Hainault, I., Hajduch, E. \& Lavau, M. (1995). Fatty genotype induced increase in GLUT4 promoter activity in transfected adipocytes: delineation of two fa-responsive regions and glucose effect. Biochemical and Biophysical Research Communications 209, 1053-1061.

Hissin, P. J., Foley, J. E., Wardzala, L. J., Karnieli, E., Simpson, I. A., Salans, L. B. \& Cushman, S. W. (1982). Mechanism of insulin-resistant glucose transport activity in the enlarged adipose cell of the aged obese rat. Relative depletion of intracellular glucose transport systems. Journal of Clinical Investigation 70, 780-790.

Kahn, B. B. (1992). Facilitative glucose transporters: Regulatory mechanisms and dysregulation in diabetes. Journal of Clinical Investigation 89, 1367-1374.

Krief, S., Bazin, R., Dupuy, F. \& Lavau, M. (1988). Increased in vivo glucose utilisation in 30 day-old obese Zucker rat: role of white adipose tissue. American Journal of Physiology 254, E342-E348.

Le Marchand-Brustel, Y., Olichon-Berthe, C., Grémaux, T., Tanti, J.-F., Rochet, N. \& Van Obberghen, E. (1990). Glucose transporter in insulin sensitive tissues of lean and obese mice. Effect of the thermogenic agent BRL 26830. Endocrinology 127, 2687-2693.

Liu, M.-L., Gibbs, E. M., McCoid, S. C., Milici, A. J., Stukenbrok, H. A., McPherson, R. K., Treadway, J. L. \& Pessin, J. (1993). Transgenic mice expressing the human GLUT4 muscle-fat facilitative glucose transporter protein exhibit efficient glycemic control. Proceedings of the National Academy of Sciences, USA 90, $11346-11350$

Pedersen, O., Kahn, R. C. \& Khan, B. B. (1992). Divergent regulation of the GLUT1 and GLUT4 glucose transporters in isolated adipocytes from Zucker rats. Journal of Clinical Investigation 89, 1964-1973.

Pénicaud, L., Ferré, P., Assimacopoulos-Jeannet, F., Perdereau, D., Leturque, A., Jeanrenaud, B., Picon, L. \& Girard, J. (1991). Increased gene expression of lipogenic enzymes and glucose transporter in white adipose tissue of suckling and weaned obese Zucker rats. Biochemical Journal 279, 303-308.

Rolland, V., Dugail, I., Le Liepvre, X. \& Lavau, M. (1995). Evidence of increased glyceraldehyde-3-phosphate dehydrogenase and fatty acid synthetase promoter activities in transiently transfected adipocytes from genetically obese rats. Journal of Biological Chemistry 270, 1102-1106.

Shepherd, P. R., Gnudi, L., Tozzo, E., Yang, H., Leach, F. \& Khan, B. B. (1993). Adipose cell hyperplasia and enhanced glucose disposal in transgenic mice overexpressing GLUT4 selectively in adipose tissue. Journal of Biological Chemistry 268, 22243-22246.

Truett, G. E., Bahary, N., Friedman, J. M. \& Liebel, R. L. (1991). Rat obesity gene fatty (fa) maps to chromosome 5: Evidence for homology with the mouse gene diabetes (db). Proceedings of the National Academy of Sciences, USA 88, 7806-7809.

Zucker, L. M. \& Zucker, T. F. (1961). Fatty, a new mutation in the rat. Journal of Heredity 62, $275-278$. 